\title{
Nomination bungle leaves CIRM leadership in limbo
}

The architect of California's $\$ 3$ billion stem cell agency is set to keep his job for a little longer. Bob Klein-the man who co-wrote the ballot initiative that created the California Institute for Regenerative Medicine (CIRM) and then served as the agency's only chairman for the past six years-was reelected by its board of directors in a near-unanimous vote last month, meaning he will stay in his post for another six months while the organization regroups in its search for a suitable successor.

State officials tasked with nominating his replacement had originally tapped current vice-chairman Art Torres as well as Alan Bernstein, executive director of the New York-based Global HIV Vaccine Enterprise as possible successors. But Bernstein, a Canadian national, was forced to pull out of the race at the beginning of December because of a state law requiring the head of a public agency to hold US citizenship, and Torres, a former state senator, withdrew his nomination a week later. As a result, Klein effectively became a shoo-in for the post.

Under the terms of the agency's statute, the board members' reappointment of Klein means he could serve as chairman for another six-year term. But the board also passed a motion calling on Klein to find a

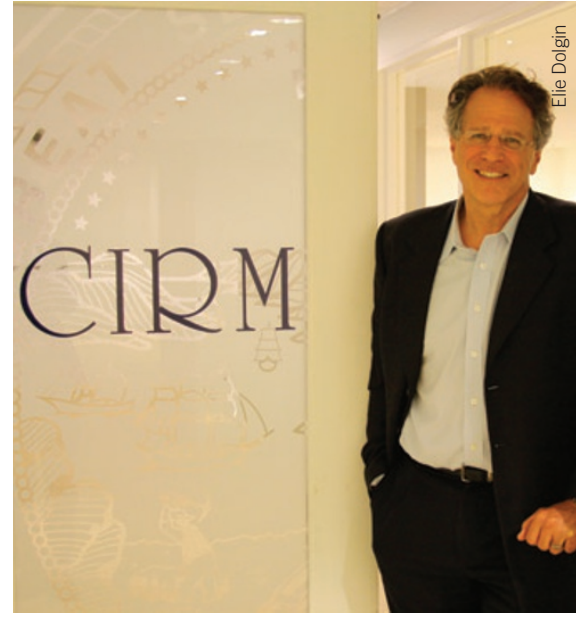

No exit: Klein stays a little longer.

replacement and step down within 180 days, if not sooner.

"I'm going to be aggressively trying to find a replacement," Klein told Nature Medicine. "Going forward here, we're going to have the time to go through a process to define the criteria" for the next chairman. Klein insists that he didn't intend to remain chairman and has agreed to stay on an unpaid, temporary basis.

Not everyone was happy with this scenario. In a strongly worded letter sent two days before the board's vote, state controller John Chiang urged the CIRM board members to delay their decision and start anew with fresh nominees. "It is clear that the current selection process is fundamentally flawed," Chiang wrote. "The taxpayers who provide the funds for CIRM must be assured that the chair and vice chair are selected in an open, transparent process-not through a backroom deal or by default because a deal has fallen apart."

"This path that they've gone down is a facesaving path for Klein, who screwed up this election by trying to manipulate it and tap his own successor," says John Simpson, stem cell project director of the Santa Monica, California-based advocacy group Consumer Watchdog. "He needs to let go and let the board step up and exercise its oversight responsibilities without constantly trying to pull the strings."

Bernstein's name is not necessarily off the table. According to Klein, the 1978 attorney general decision ruling the requirement of US citizenship for holding public office may be unconstitutional. The state attorney general's website states that such opinions "have been accorded 'great respect' and 'great weight' by the courts," but they do not technically define the law.

Elie Dolgin

\section{Conference brings Asia-Pacific research funding scheme closer}

For several years, the idea of a multinational funding scheme to support research in the Asia-Pacific region has been brewing. Finally, at the biannual Australian Health and Medical Research Congress late last year, policymakers publicly discussed the merits and challenges of such a venture for the first time.

The congress in Melbourne, convened by the Australian Society for Medical Research (ASMR), attracted about 1,500 delegates from 18 countries. Dignitaries at the November event included Australia's minister for mental health and aging and the acting consul-general of Japan.

Alison Butt, who held the post of ASMR president until the congress, says that with the numbers of scientists in countries such as China overtaking numbers in the US, the Asia-Pacific region should combine forces to nurture the growth of local medical research.

"The Society feels that there are enormous benefits to collective schemes that will fund projects that combine the region's scientific resources and capabilities," she says. "We have evidence for economic gains in health and medical research that extend from reducing disease burden and associated healthcare costs to minimizing work absence. There's also a case to be made in ensuring there's a critical mass of appropriately trained scientists to meet industry demands." The EU's Framework Programme funding scheme is held up as one potential model of multinational collaboration. The Framework Programme, now in its seventh iteration, has a budget of $€ 50$ billion ( $\$ 66$ billon), of which a little bit less than $10 \%$ is allocated for health research. The $27 \mathrm{EU}$ member nations commit approximately $3 \%$ of their GDP to the scheme, on average.

The scale of funding for the proposed Asia Pacific Health and Medical Research Funding Union (APHMRFU) was not discussed in detail, but it would most likely be pegged to a percentage of GDP. ASMR plans to issue a statement and will begin preparing a proposal for the Asia Pacific Parliamentary Forum in early 2012.

"Asia's population is aging more rapidly than in the rest of the world; in some countries the number of people over 65 is increasing at $3 \%$ per year-twice the rate in most Western 